\title{
Unique occurrence of polychelidan lobster larvae in the fossil record and its evolutionary implications
}

Joachim T. Haug ${ }^{\text {a,* }}$, Denis Audo ${ }^{\text {b }}$, Carolin Haug ${ }^{\text {a }}$, Pierre Abi Saad ${ }^{\text {c }}$, Gilles Petit ${ }^{\text {d, Sylvain }}$ Charbonnier $^{\mathrm{b}}$

${ }^{a}$ Department of Biology II and GeoBio-Center, LMU Munich, Grosshaderner Str. 2, 82152 Planegg-Martinsried, Germany

${ }^{\mathrm{b}}$ Département Histoire de la Terre, CP38, UMR 7207 CR2P CNRS-UPMC-MNHN, Muséum national d'Histoire naturelle, 57 rue Cuvier, 75231 Paris, France

${ }^{\mathrm{c}}$ Memory of Time, Citadel area, 26111 Byblos, Lebanon (www.memoryoftime.com)

${ }^{\text {d }}$ Département Histoire de la Terre, CP48, UPMC-LIS-Paléoparasitologie, UMR 7207 CR2P CNRSUPMC-MNHN, Muséum national d'Histoire naturelle, 57 rue Cuvier, 75231 Paris, France

*Corresponding author: joachim.haug@palaeo-evo-devo.info

\begin{abstract}
Larvae represent a specific life phase of an organism and often have very different life habits and thus morphology than the adult. Like in adults, also larval traits most likely evolved gradually. We describe a new larval form, recently discovered in the about 95 million years old (Cenomanian, Late Cretaceous) Plattenkalks of Hadjoula (Lebanon). The two known specimens possess larval characters and can be ascribed to polychelidan lobsters. They represent the youngest nonambiguous polychelidan in the fossil record and the single known occurrence of a fossil larval form of a polychelidan lobster. Like their modern counterparts, eryoneicus larvae of Polychelidae, these fossil larvae are relatively large and armed with numerous spines on their shield (carapace) and pleon. They differ from extant eryoneicus larvae by their unusually long rostrum, their stalked eyes with a developed cornea and a shield far less inflated than the balloon-like shield of modern eryoneicus larvae. These fossil larvae demonstrate that the highly specialised morphology of modern polychelid larvae evolved gradually and give important clues in which temporal order these larval specialisations evolved. The specimens are another example of fossils providing crucial insights into the evolution of specialised developmental patterns of modern groups, as previously demonstrated for mantis shrimps, achelate lobsters, or early crustaceans, but also for other animal groups.
\end{abstract}

Keywords: Cretaceous; Hadjoula; eryoneicus larva; metamorphosis; larval specialisation.

\section{Introduction}

Early developmental stages, including larvae, can apparently evolve independently from the adult (Scholtz, 2005). Yet, the evolution of larval forms is still controversial in many aspects, and has also triggered rather unusual evolutionary theories (e.g., Williamson, 2012 and references therein; but see Hart and Grosberg, 2009; Willis and Cox-Foster, 2010). For understanding the evolution of specific larval traits, some evolutionary lineages are especially interesting: those in which highly specialised larvae derived from less specialised ones, or directly from a juvenile in the case of ancestors with a direct development. For such cases, a gradual evolution of larval traits with further and further specialised larval types appears to be a plausible evolutionary scenario.

For the evolution of adult forms the fossil record has provided early representatives of various lineages that allowed very detailed reconstructions of evolutionary scenarios, with very 
gradual, step-by-step transformations leading to the modern morphologies (e.g., Senter, 2010; Haug et al., 2010a). Such approaches have as well been applied successfully to developmental traits

\section{Material and methods}

All studied specimens (fossil and extant) are part of the collection of the Muséum national d'Histoire naturelle Paris. The two fossil specimens were found in in the quarry of Hadjoula, Lebanon by one of the authors (Pierre Abi Saad). Fossils from this quarry are about 95 million years old (Cenomanian, Late Cretaceous). The age is based upon ammonite fauna (Hückel, 1970; Hemleben, 1977) and was confirmed by Wippich and Lehmann (2004). Geological settings have been summarized in Audo and Charbonnier $(2012,2013)$.

Documentation followed the macro-fluorescence approach of Haug et al. (2011b) with a Canon Rebel T3i and a MP-E 65mm macro lens. Several images were recorded and stitched with Adobe Photoshop CS 3 (photomerge, reposition only or interactive layout).

Extant specimens were documented directly in alcohol under cross-polarised light with the same camera; smaller specimens with a MP-E 65mm macro lens, larger ones with an EF-S 18$55 \mathrm{~mm}$ lens. Lighting was provided by a Canon Twin Flash MT-24. Several images were recorded at different focal planes to produce an image stack. Stacks were fused with the software programs CombineZM/ZP (for technical details see Haug et al., 2011b).

\section{Description of the fossil specimens}

\subsection{Large specimen (MNHN.F.A48983)}

Total length about $30 \mathrm{~mm}$ (Fig. 1A). Cephalothorax possesses a conjoined tergal area forming a cephalothoracic shield (carapace). Shield is anteriorly drawn out into a rostrum and armed with numerous spines grouped into about eleven rows from the rostrum to the posterior margin, with up to eleven spines per row ( 5 on each side, one along dorso-median axis); between the spines 
numerous fine (probably sensorial) setae are present (Fig. 1B). The pleon segments bear large spines along their median line. The tergopleura are drawn out into two spines each. The first pleomere appears to bear five spines along its dorsal side ( 2 on each side, one median); the same pattern is seen on pleomeres 4-6. Pleomeres 2-3 have two rows of five spines each. The tail fan consists of an acute triangular telson and the uropodal rami, which appear also more or less triangular, but shorter than the telson. The first pereiopod is only incompletely preserved, but appears larger than the succeeding one; the fixed finger appears to be preserved, but bent. Pereiopods 2-4 are sub-similar; distally they all bear tiny chelae (also the fourth pereiopod; Fig. 1C). The distal section of pereiopods, near the chela bears a row of elongate setae (Fig. 1C).

\subsection{Small specimen (MNHN.F.A49029)}

The second specimen is considered to be an earlier stage (see discussion). Total length about $14 \mathrm{~mm}$ (Fig. 1D). The smaller specimen is preserved with fewer details, yet preserves aspects not observable on the larger specimen, e.g., the shield is more complete. The rostrum shows two additional spines on the ventral side. Shield bears eleven rows of spines. Under the rostrum a spherical structure most likely represents the compound eye, with a cornea, possibly with squareshaped facets (Fig. 2A, B). Pleon and appendages are less well known. The pleomeres are also spinose and equipped with paired spines on the tergopleurae. Thoracopods 5-8 also possess tiny chelae and setal rows (Fig. 1E). Uropodal rami are also triangular and shorter than the, likewise triangular, telson.

\section{Discussion}

\subsection{Systematic position}

Specimens MNHN.F.A48983 and A49029 are considered to be conspecific and to represent different ontogenetic stages. The assumption of conspecifity is based on several similarities, namely the spination of shield and pleomeres, the setae equipment, the stout chelae and the length ratios of uropods and telson. All differences, mainly the stouter general appearance of the smaller specimen, can well be understood as result of an ontogenetic effect.

Both specimens possess five well-developed pereiopods (= thoracopods 4-8), six pleomeres, and a shield covering the entire cephalothorax, a typical decapod crustacean habitus. Within decapods, the specimens can be confidently ascribed to Polychelida based on the following points:

(1) Their pereiopods $2-4$ bear a chela - especially the presence of a claw on pereiopod 4 is a very rare feature in decapods besides Polychelida. The chelae are quite small, the exact joint appears to be below the resolution of the fossil. Yet, also in modern forms the fingers of the chelae can be very small and appear to be not necessarily functional yet, even in large larvae. It is also worth noting that the propodus is quite short in the specimens, while the carpus (as well as the merus) is quite long. While a relatively long carpus might appear unusual for a decapod at first sight, such a morphology is also found in modern eryoneicus larvae (Bernard, 1953, his figs. 4, 20.1).

(2) The pleon morphology resembles that of many non-meiuran reptantians in appearing more dorsoventrally flattened (as indicated by the orientation of the embedding). In caridean shrimps the pleon usually possesses a distinct bent at the third pleomere, while here the pleon is smoothly curved (as in lobsters). Furthermore, affinities to carideans (including the heavily armoured glyphocrangonids, which distantly resemble the here described specimens) can also be excluded as in carideans the tergopleura of pleomere two are significantly enlarged to overlap the tergopleura of pleomeres one and three. This is obviously not the case in the here described specimens.

(3) While the pleon morphology indicates reptantian affinities, the telson morphology resembles that of caridean and dendrobranchiate shrimps, as it is acute triangular. Such a triangular telson rarely occurs in reptantians, the major exceptions being glypheideans (Charbonnier et al. 
2013) and polychelidans (most species, DA, personal observations). Most other reptantian lobsters, including the spiny achelate lobsters, possess a distinctly subrectangular telson. Hence, this specific combination, with apomorphic characters of reptantians (pleon) and the retention of plesiomorphic decapod characters (telson) is only found in Reptantia outside Eureptantia. Together with the morphology of the posterior thoracopods (chelae, long carpus in larvae) clearly indicate polychelidan affinities of the here described specimens.

(4) The very spinose shield and pleon (Figs. 2C, 3) indicate the larval status of the here described specimens. In addition, the comparably small size, the density of setae on shield and appendages, and the relatively short length of dactylus and fixed finger of the posterior chelae undoubtedly indicate that both specimens have not reached an adult morphology through metamorphosis. These specimens can be considered to represent a developmental stage equivalent to the eryoneicus larvae of modern Polychelidae.

(5) Both specimens clearly possess a marked cervical groove. Marked cephalothoracic grooves occurs in most decapod crustaceans, including most species of polychelidan lobsters except for Eryon cuvieri, all species of Cycleryon and Knebelia bilobata (Audo et al 2014a,b), in which it is almost effaced. For this reason, the presence of a marked cervical groove does not preclude an ascription to polychelidan lobsters.

\subsection{Evolution of eryoneicus larvae in polychelidan lobsters}

Polychelidan lobsters first occur in the fossil record about 230 mya (Late Triassic, Carnian). Surprisingly, no juvenile specimen is known before about 170 mya (Middle Jurassic, BathonianBajocian of Monte Falano: Bravi et al. 2014). Other reported juvenile specimens are younger, about 165 mya (Callovian: Charbonnier, 2009; Charbonnier et al., 2010, in press) and about 150 mya (Kimmeridgian-Tithonian: Audo et al., 2014a). During the Cretaceous (145-65 mya) the polychelidan fossil record is very scarce, with only three species, each represented by a single specimen (Garassino et al., 2012 and references herein).

Dated from the Late Cretaceous, the here described specimens are only the second "eryoneicus-type" larvae reported, the other being Eryoneicus sahelalmae Roger, 1944 from the Santonian of Lebanon, a deep-sea palaeoenvironment (Audo and Charbonnier, 2013). However, the latter species has recently been reinterpreted as an achelate late larva or early juvenile (Haug et al. 2009, 2011a, 2013). Our specimens therefore represent the single known occurrence of an "eryoneicus-type" larva in the fossil record.

After the Cretaceous, only one fossil was ascribed with doubt to polychelidan lobsters: Palaeopentacheles? starri Schweitzer and Feldmann, 2001 (Schweitzer and Feldmann, 2001). However, a reinvestigation of the specimen shows that the structures in this fossil were misinterpreted: the specimen is a moult, a pectinate claw corresponds to a pair of third maxillipeds with their crista dentata, and the poorly preserved shield seems to be laterally flattened, as in nephropoid lobsters. This species is perhaps a nephropoid lobster, which implies that our larval specimens correspond to the last known occurrence of polychelidan lobster in the fossil record.

As MNHN.F.A48983 and A49029 can be recognised as "eryoneicus-like" larvae, but differ from modern forms, we can propose some conclusions about the evolution of larval traits within the polychelid lineage. With juveniles characterized by a small size and morphologies rather similar to that of the adult, it seems that most Jurassic groups such as Eryonidae, Palaeopentachelidae and perhaps Coleiidae did not possess an "eryoneicus-type" larva: the smallest specimens known of these polychelidan groups are significantly smaller than late stage eryoneicus larvae and than specimen MNHN.F.A48983 (Bernard, 1953). Yet, these small polychelidans show no specialised larval traits such as the spinose shield or pleon, but instead roughly resemble their corresponding adults. This also means that the larval phase of these earlier forms was comparably short and that the juvenile phase was longer, hence from small sizes onwards the adult morphology was established. In modern forms this is quite the opposite: the larval phase lasts longer, the adult morphology is established rather late. Thus, the late larval stages are quite large compared to the adult size (not necessarily in absolute dimensions). 
Specimens MNHN.F.A48983 and A49029 therefore can be understood as an evolutionary 'step-in-between', developing through specialised stages, which already possess some of the larval features of a modern eryoneicus, but not all of them:

(1) retention of eyes,

(2) a well-developed rostrum (as developed in most decapod larvae) and

(3) a non-balloon-shaped shield

which are all plesiomorphic characters, thus supporting the assumption of an evolutionary intermediate form. As a consequence, we can conclude that the relatively large size of the larvae of the specimens, which they share with modern forms, as well as the pronounced spination and setation, as also seen in their modern counterpart, evolved first and led to the larvae described herein (Fig. 3). Later in the evolutionary lineage towards modern polychelids additional specialisations must have evolved, such as the balloon-shaped shield and the reduction of the rostrum (Fig. 3).

Most fauna from Hadjoula probably used to live in the euphotic zone, some probably living in the reefs surrounding the depression where the Lagerstätte was deposited (Hückel, 1970; Hemleben, 1977; Audo and Charbonnier, 2012). With their functional cornea, both studied larvae probably did not live in a deep-sea environment. Thus, the additional characters of modern eryoneicus larvae could have been coupled to a habitat change into deeper waters. In this respect, it should be noted that no adult polychelidan lobster has ever been reported from Lebanon. As modern eryoneicus larvae probably grow in a different environment than where the adults live, it is possible that the lack of adult polychelidans in Lebanon, and perhaps also their extreme rarity in the Cretaceous, may result from adults living preferentially in deep water.

\subsection{Gradual evolution of larval traits}

The case of specimens MNHN.F.A48983 and A49029 is seen as an important example of a stepwise evolutionary acquisition of larval features. Other recently described examples of fossil arthropod larvae could also represent such examples of less specialised larvae (compared to their modern counterparts), e.g., mantis shrimps or achelate lobsters (Haug and Haug, 2013). Yet, it is more likely that the latter forms represent ontogenetically transitional forms from already highly specialised larvae to the juvenile. As the smaller specimen A49029 clearly lacks the same larval specialisations as the larger specimen, the two cannot be interpreted as such ontogenetically transitional forms. The here presented case therefore represents the first clear example of a stepwise evolution of larval traits in crustaceans.

Haug and Haug (2013) had hypothesised that the evolution of metamorphosis as a specific developmental pattern was coupled to two factors: 1) evolutionary increase of disparity of early (larval) stages, and 2) condensation of gradual developmental patterns with numerous moults to few drastic metamorphic moults. While other described fossil crustacean larvae can exemplify the second point (e.g., Walossek, 1993), this new case of polychelidan larvae is the first reliable example for point one.

Polychelids are often considered to have a "direct development" (Gurney, 1942, p. 229), most likely referring to a non-metamorphic type of ontogeny. Yet, the specialisations of their larval stages speak against such an assumption. Until now no ontogenetic transitionary forms are known, which would bridge eryoneicus larvae and juvenile stage polychelidans, as the development of these deep-sea forms is impossible to study directly. This indicates that the last moult of the larva in modern polychelids is a metamorphic one. Given this consideration, polychelids are, together with the newly discovered fossils, another potential group for studying the evolution of development and metamorphosis with a palaeo-evo-devo approach.

\section{Acknowledgments}

The authors wish to thank J.-M. Pacaud and P. Martin-Lefèvre (MNHN) for the access to palaeontological and extant crustacean collections. Gideon T. Haug, Neuried, is thanked for 
photographic assistance. JTH was kindly supported by the Alexander von Humboldt foundation with a Feodor Lynen return fellowship. The visit of JTH to the MNHN was funded by a grant from the European Commission's (FP 6) Integrated Infrastructure Initiative programme SYNTHESYS (FR-TAF 2590). This work is part of the project "Palaeo-Evo-Devo of Malacostraca" kindly supported by the German Research Foundation (DFG) under HA 6300/3-1. CH was supported by the German Academic Exchange Service (DAAD) with a return fellowship. The field campaign was supported by the UMR 7207 CR2P (CNRS/MNHN/UPMC) and ATM "Biodiversité actuelle et fossile" (MNHN).

\section{References}

Audo, D., Charbonnier, S., 2012. New nisto of slipper lobster (Decapoda: Scyllaridae) from the Hadjoula Lagerstätte (late Cretaceous, Lebanon). Journal of Crustacean Biology 32, 583-590. (DOI: 10.1163/193724012X634189).

Audo, D., Charbonnier, S., 2013. Late Cretaceous crest-bearing shrimps from the Sahel Alma Lagerstätte of Lebanon. Acta Palaeontologica Polonica 58, 335-349. (DOI: /10.4202/app.2011.0056)

Audo, D., Charbonnier, S., Schweigert, G \& Saint Martin, J.-P. 2014b. New eryonid crustaceans from the Late Jurassic Lagerstätten of Cerin (France), Canjuers (France), Wattendorf (Germany) and Zandt (Germany). Journal of Systematic Palaeontology 12, 459-479.

Audo, D., Schweigert, G., Haug, J.T., Haug, C., Saint Martin, J.-P., Charbonnier, S., 2014a. Diversity and palaeoecology of the enigmatic genus Knebelia (Eucrustacea, Decapoda, Eryonidae) from Upper Jurassic Plattenkalks in Southern Germany. Palaeontology 57, $397-$ 416. (DOI: 10.1111/pala.12071).

Bernard, F., 1953. Decapoda Eryonidae (Eryoneicus et Willemoesia). Dana Report 37, 1-93.

Bravi, S., Garassino, A., Bartiromo, A., Audo, D., Charbonnier, S., Schweigert, G., Thévenard, F. \& Longobardi, C., 2014. Middle Jurassic Monte Fallano Plattenkalk (Campania, southern Italy): first report on terrestrial plants, decapod crustaceans and fishes. Neues Jahrbuch für Geologie und Paläontologie, Abhandlungen 272, 79-107.

Butterfield, N.J., Harvey, T.H.P., 2012. Small carbonaceous fossils (SCFs): a new measure of early Paleozoic paleobiology. Geology 40, 71-74.

Charbonnier, S., 2009. Le Lagerstätte de La Voulte: un environnement bathyal au Jurassique. Mémoires du Muséum national d'Histoire naturelle 199, 1-265.

Charbonnier, S., Audo, D., Caze, B. \& Biot, V., in press. The La Voulte-sur-Rhône Lagerstätte (Middle Jurassic, France). Comptes Rendus Palevol.

Charbonnier, S., Garassino, A., Schweigert, G., Simpson, M., 2013. A worldwide review of fossil and extant glypheid and litogastrid lobsters (Crustacea, Decapoda, Glypheoidea). Mémoires du Muséum national d'Histoire naturelle, Paris 205, 1-304.

Charbonnier, S., Vannier, J., Hantzpergue, P., Gaillard, C., 2010. Ecological significance of the arthropod fauna from the Jurassic (Callovian) La Voulte Lagerstätte. Acta Palaeontologica Polonica 55, 111-132.

Galil, B.S., 2000. Crustacea Decapoda: review of the genera and species of the family Polychelidae Wood-Mason, 1874. In: Crosnier, A. (Ed.), Résultats des campagnes MUSORSTOM, Volume 21. Mémoires du Muséum national d'Histoire naturelle 184, 285-387.

Garassino, A., Pini, G.A., Pasini, G., 2012. First report of a polychelid lobster (Crustacea: Decapoda: Coleiidae) from the Early Cretaceous of Italy. Neues Jahrbuch für Geologie und Paläontologie, Abhandlungen 263, 47-55.

Gurney, R., 1942. Larvae of Decapod Crustacea. Adlard and Son, London.

Hart, M.W., Grosberg, R.K., 2009. Caterpillars did not evolve from onychophorans by hybridogenesis. Proceedings of the National Academy of Sciences of the United States of America 106, 19906-19909. 
Haug, J.T., Haug, C., Waloszek, D., Maas, A., Wulf, M., Schweigert, G., 2009. Development in Mesozoic scyllarids and implications for the evolution of Achelata (Reptantia, Decapoda, Crustacea). Palaeodiversity 2, 97-110.

Haug, J.T., Haug, C., Maas, A., Kutschera, V., Waloszek, D., 2010a. Evolution of mantis shrimps (Stomatopoda, Malacostraca) in the light of new Mesozoic fossils. BMC Evolutionary Biology 10, art. 290, 17 pp.

Haug, J.T., Maas, A., Waloszek, D., 2010b. †Henningsmoenicaris scutula, $\uparrow$ Sandtorpia vestrogothiensis gen. et sp. nov. and heterochronic events in early crustacean evolution. Earth and Environmental Science Transactions of the Royal Society of Edinburgh 100, 311-350.

Haug, J.T., Haug, C., Waloszek, D., Schweigert, G., 2011a. The importance of lithographic limestones for revealing ontogenies in fossil crustaceans. Swiss Journal of Geosciences 104, Supplement 1, S85-S98.

Haug, J.T., Haug, C., Kutschera, V., Mayer, G., Maas, A., Liebau, S., Castellani, C., Wolfram, U., Clarkson, E.N.K., Waloszek, D., 2011b. Autofluorescence imaging, an excellent tool for comparative morphology. Journal of Microscopy 244, 259-272.

Haug, J.T., Audo, D., Charbonnier, S., Haug, C., 2013. Diversity of developmental patterns in achelate lobsters - today and in the Mesozoic. Development Genes and Evolution 223, 363373.

Haug, J.T., Haug, C., 2013. An unusual fossil larva, the ontogeny of achelatan lobsters, and the evolution of metamorphosis. Bulletin of Geosciences 88, 195-206.

Hemleben, C., 1977. Rote Tiden und die oberkretazischen Plattenkalke im Libanon. Neues Jahrbuch für Geologie und Paläontologie, Monatshefte 4, 239-255.

Hückel, U., 1970. Die Fischschiefer von Haqel und Hjoula in der Oberkreide des Libanon. Neues Jahrbuch für Geologie und Paläontologie, Abhandlungen 135, 113-149.

Martin, J.W., in press. Infraorder Polychelida. In: Martin J.W., Olesen, J., Høeg, J.T. (Eds.), Atlas of Crustacean Larvae. Johns Hopkins University Press.

Sánchez-Villagra, M.R., 2012. Embryos in Deep Time. University of California Press, San Francisco.

Scholtz, G., 2005. Homology and ontogeny: pattern and process in comparative developmental biology. Theory in Biosciences 124, 121-143.

Schweitzer, C.E., Feldmann, R.M., 2001. New Cretaceous and Tertiary decapod crustaceans from western North America. Bulletin of the Mizunami Fossil Museum 28, 173-210.

Senter, P., 2010. Using creation science to demonstrate evolution: application of a creationist method for visualizing gaps in the fossil record to a phylogenetic study of coelurosaurian dinosaurs. Journal of Evolutionary Biology 23, 1732-1743.

Walossek, D., 1993. The Upper Cambrian Rehbachiella and the phylogeny of Branchiopoda and Crustacea. Fossils and Strata 32, 1-202.

Williamson, D.I., 1983. Crustacea Decapoda: Larvae. VIII. Nephropidae, Palinuridae, and Eryonidae. Fich. Ident. Zooplankton 167/168, 8pp.

Williamson, D.I., 2012. The origins of chordate larvae. Cell and Developmental Biology 1, 101.

Willis, J.H., Cox-Foster, D.L., 2010. Insect metamorphosis via hybridogenesis: An evidentiary rebuttal. Journal of Insect Physiology 56, 333-335. (DOI: 10.1016/j.jinsphys.2009.11.007)

Wippich, M.G.E., Lehmannn J., 2004. Allocrioceras from the Cenomanian (mid-Cretaceous) of the Lebanon and its bearing on the palaeobiological interpretation of heteromorphic ammonites. Palaeontology 47, 1097-1107. 


\section{Figure captions}

Fig. 1. Fossil polychelid eryoneicus larvae (Hadjoula; Cretaceous, Lebanon). A-C, larger specimen (MNHN.F.A48983). A, overview image, showing the spiny appearance of the specimen. B, closeup on the setae on the shield. C, fourth pair of pereiopods (= seventh pair of thoracopods), also bearing chelae, a character for polychelidans. D-E, smaller specimen (MNHN.F.A49029). D, overview, same scale as A. E, close-up on fourth pair of walking legs with chelae. ch, chela; cs, cephalothoracic shield; es, eye structure; f?, possible finger; $p$, pereiopod; pl, pleomere; rs, rostrum; tf, tail fan.

Fig. 2. Eye of fossil specimen and extant specimens for overall comparison. A-B, close-up on eye of smaller fossil eryoneicus larva (MNHN.F.A49029). A, close-up. B, detail of A with colourmarked ommatidia. C, two extant eryoneicus larvae for comparison with the fossil ones; undetermined species, also unclear if the specimens are conspecific; left MNHN PA 1165, right MNHN PA 1125.

Fig. 3. Reconstruction of the fossil eryoneicus larvae and evolutionary scenario. Top: 3D reconstruction of the larger specimen; not preserved body parts amended from extant eryoneicus larvae. Bottom: Evolutionary scenario describing the step-wise acquisition of larval characters in the evolutionary lineage towards modern polychelids. Developmental pattern unclear for Tetrachelidae and Coleiidae. 
Figure 1
Click here to download high resolution image
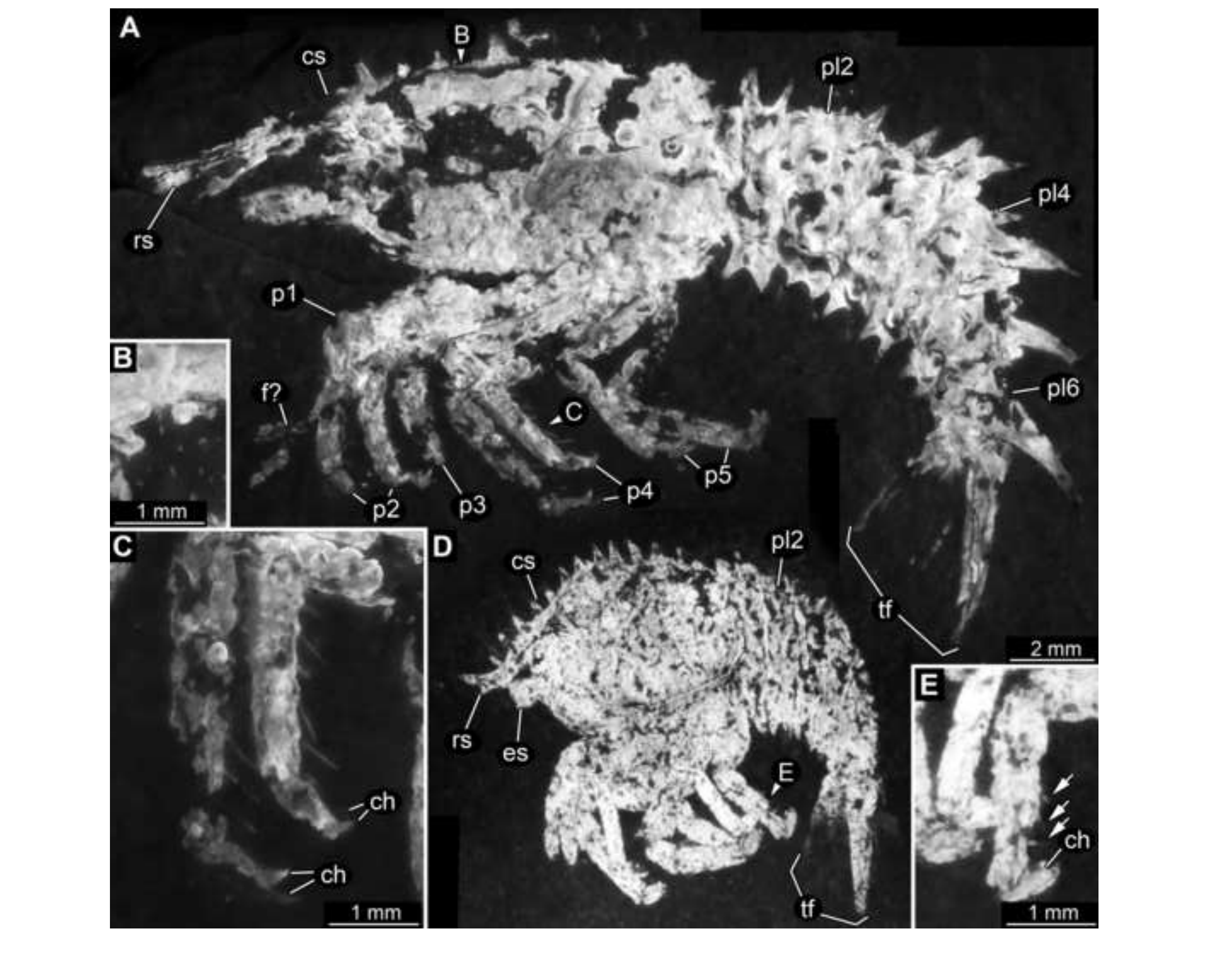

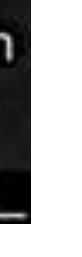

. 
Click here to download high resolution image
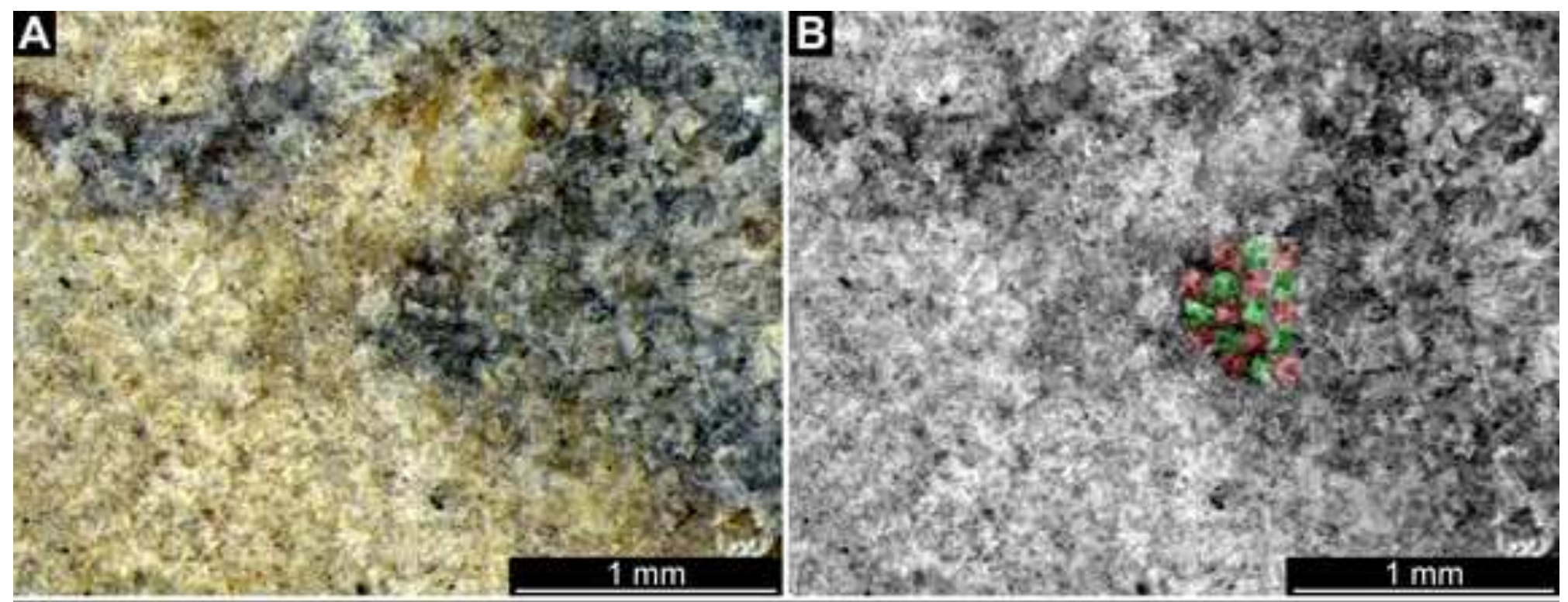

C

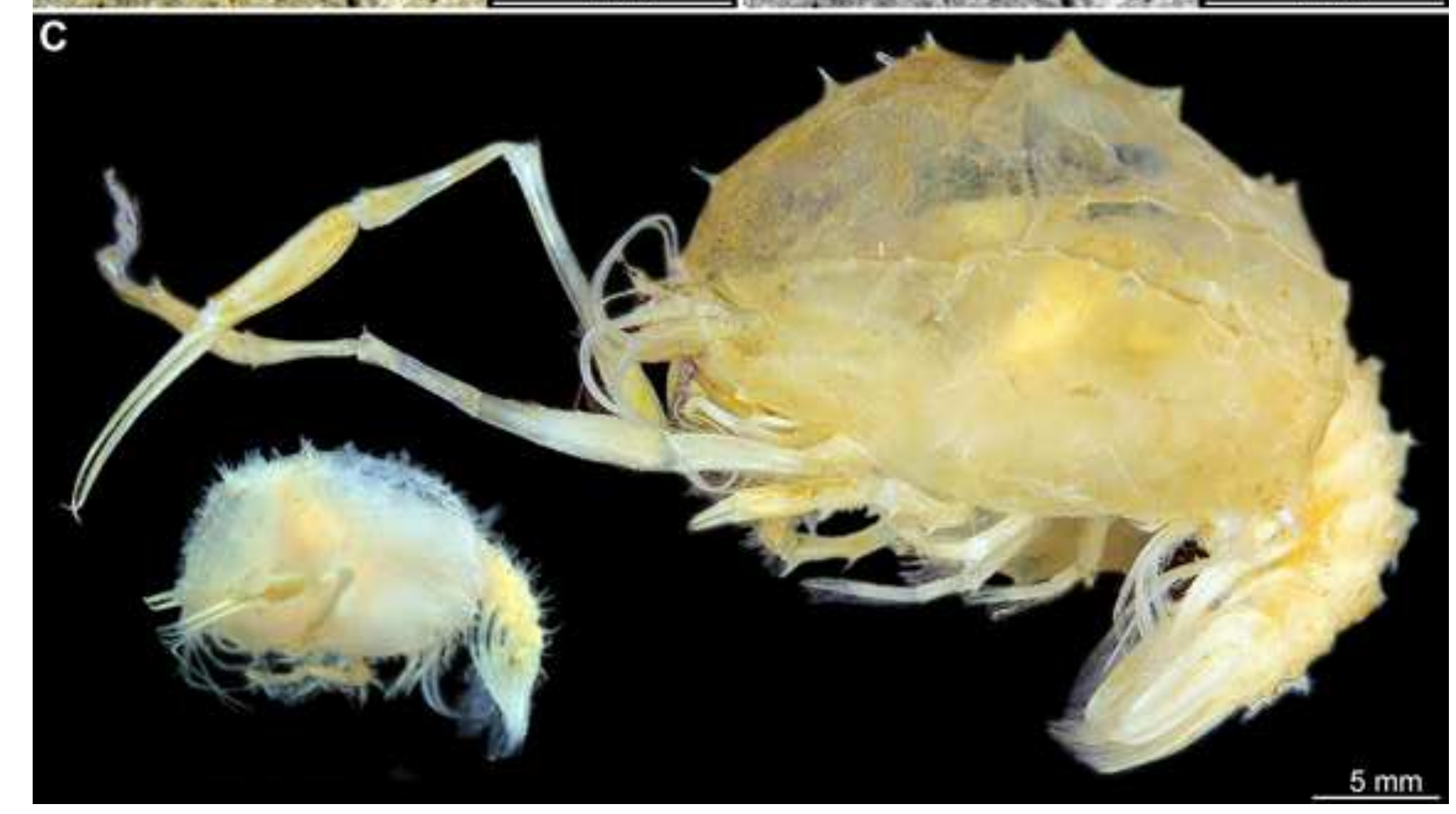




\section{Click here to download high resolution image}

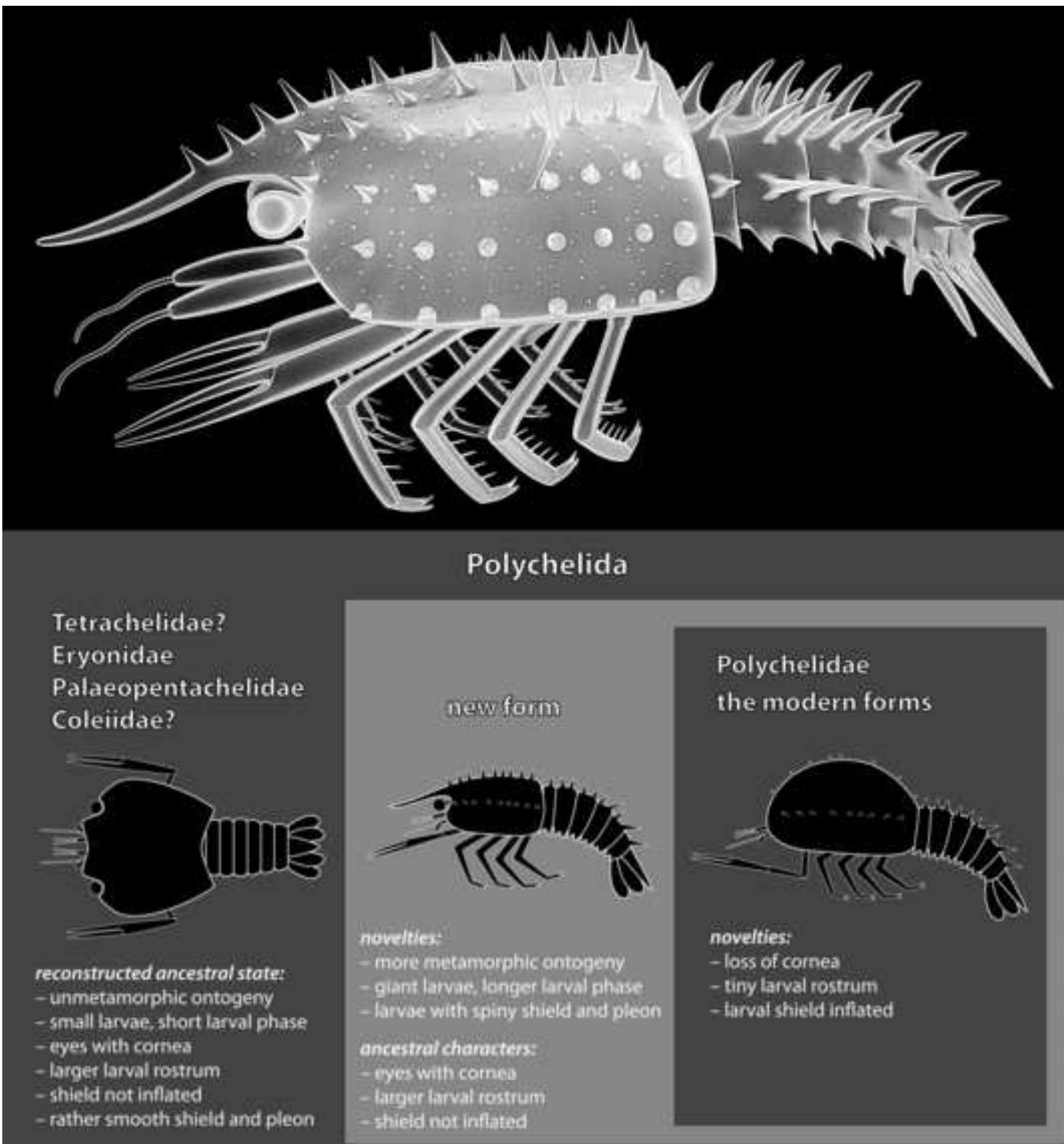

